УДК [005.336.2:316.46]:378

Світлана Нестуля, кандидат історичних наук, дочент кафедри управління персоналом та економіки прачі, директор навчально-наукового інституту лідерства ВНЗ Укоопспілки «Полтавський університет економіки і торгівлі»

\title{
КОМПЕТЕНТНІСНИЙ ПІДХІД ДО ФОРМУВАННЯ ЛІДЕРСЬКОЇ КОМПЕТЕНТНОСТІ МАЙБУТНІХ БАКАЛАВРІВ 3 МЕНЕДЖМЕНТУ В УНІВЕРСИТЕТІ
}

У статті здійснено теоретичний аналіз компетентнісного підходу у вищій освіті. 3'ясовано сутність компетентнісного підходу до формування лідерської компетентності майбутніх бакалаврів 3 менеджменту з позииї сучасної дидактики, яка полягає у цілеспрямованій організації освітнього прочесу в університеті, покликаного забезпечити розвиток лідерських якостей науково-педагогічних працівників і студентів. Виявлено, що ключовими формами навчання студентів $є$ тренінгові технології. Сутність компетентнісного підходу до формування лідерської компетентності майбутніх бакалаврів з менеджменту розкрито у Програмі розвитку лідерських якостей науково-педагогічних працівників $i$ студентів на 2017-2022 роки.

Ключові слова: компетентність, лідерська компетентність, компетентнісний підхід, бакалавр, менеджер, університет, тренінг, майстер-клас.

The article deals with a theoretical analysis of the competence approach in higher education. Leadership competence of future bachelors in management is treated as a combination of established leadership qualities (motives, knowledge, leadership skills and a strong leadership position) and practical leadership experience. The essence of the competent approach to forming the leadership competence of future bachelors of management from the position of modern didactics is the purposeful organization of the educational process at the university, designed to ensure the development of leadership skills of scientific and pedagogical workers, students. It promotes effective solution of actual and potential professional tasks. The key forms of student learning are training technology, through which students learn to identify the main directions of their future pedagogical professional activity, its goals and perspectives, to form leadership competence, refine their reflexive characteristics, adapt to future professional activities, be a successful manager of the leader. The essence 
of the competent approach to the formation of leadership competence of future bachelors in management is disclosed in the Program for the development of leadership qualities of scientific and pedagogical workers and students in 20172022. This program represents the content of education at the university, whose main purpose is the formation of leadership competency of students. Purpose of the program is the following: the formation and development of soft skills. Soft skills are skills that allow you to be successful regardless of the specificity of the activity or the direction in which a person works. The objectives of the program are to provide for the formation of such skills: interpersonal communication, to be persuasive, to approach people, to negotiate, to be able to work in a team, non-conflict, stress tolerance, time management, creativity, persistent personal development, openness to learning and readiness to share knowledge, strive to innovations, readiness for challenges, initiative, set goals, achievement of result, decision-making, development of talent. All of these qualities are recognized as key competencies in modern companies that build their leadership skills.

Keywords: competence, leadership competence, approach, bachelor, manager, university, training, master class.

В епоху соціально-економічних і технологічних трансформацій, зростання ролі знань, інновацій i їх носіїв та ініціаторів - людей організації, установи та країни можуть успішно розвиватися лише в рамках лідерської управлінської парадигми. У зв'язку з цим, розвиток суспільства як в Україні, так і в світі в цілому ставить перед вищою освітою нові вимоги до підготовки випускників - бакалаврів з менеджменту з високим рівнем лідерської компетентності, конкурентноспроможних, здатних згуртовувати колектив та спрямовувати його на досягнення важливих цілей, надихати на успішну діяльність, викликати довіру колективу до владних повноважень керівника. Актуалізація питання посилена прийняттям в Україні Національної рамки кваліфікацій (Постанова КМУ № 1341 від 23.11.2011 р.), новою редакцією Закону України «Про вищу освіту» (№ 1556-УІІ від 01.07.2014р.) та Ратифікацією Угоди про асоціацію з СС (16 вересня 2014 р.).

Проблематику професійної підготовки менеджерів різноаспектно висвітлювали у своїх працях вітчизняні та зарубіжні учені: 3 позиції формування та розвитку професійної компетентності менеджерів (А. Алексюк, І. Бех， В. Галузинський, В. Демчук， М. Свтух， Н. Ничкало, I. Зязюн); професійно важливих якостей (В. Агєєв, А. Алексєєв, В. Бондарев, А. Боровський, В. Васильєв, Г. Щокін, А. Чернявський) та професійної культури (І. Ладанов, С. Паркінсон, О. Пономарьов, О. Романовський $Ф$. Хміль, В. Шепель); удосконалення професійної підготовки менеджерів (Л. Влодарска-Зола, О. Капітанець, Н. Ушакова). Сутність формування лідерської компетентності розкривали у своїх 
дослідженнях О. Бойко, О. Видрашко, Т. Волосюк, В. Жигірь, О. Срмоленко, В. Лугова, Н. Мараховська, С. Козловська, Г. Падурець, О. Долгопол, С. Тарасова, І. Чудаєва. Незважаючи на значну кількість наукових праць, проблема розкриття сутності компетентнісного підходу до формування лідерської компетентності майбутніх бакалаврів 3 менеджменту в університеті 3 позиції сучасної дидактики ще потребує досліджень.

Мета статті - розкрити сутність компетентнісного підходу до формування лідерської компетентності майбутніх бакалаврів 3 менеджменту в університеті з позиції сучасної дидактики.

Не викликає сумніву той факт, що нині велику роль в освітньому процесі вищої школи відіграє компетентнісний підхід. До нього ставляться вимоги забезпечення сформованості професійних якостей, професійної компетентності, поведінкових актів та виконавчих дій на рівні посадових вимог можливого працевлаштування $\mathrm{i}$, в той же час, на рівні вимог наступного освітнього рівня (у разі продовження освіти) [9].

У працях вітчизняних та зарубіжних педагогів досить широко висвітлено поняття компетентнісного підходу у вищій освіті. Так, В. Андрущенко визначає компетентнісний підхід як нову парадигму формування компетентних фахівців, що передбачає включення в систему комплексної стандартизації якості вищої освіти таких новоутворень, як конкурентоспроможність і конкурентноздатність [1]. Г. Селевко трактує компетентнісний підхід як поступову переорієнтацію домінуючої освітньої парадигми 3 переважаючою трансляцією знань і формування навичок до створення умов для оволодіння комплексом компетенцій [13].

Згідно позиції В. Болотова та В. Сєрікова, компетентнісний підхід це надання переваги не поінформованості студента, а його вмінню вирішувати проблеми [3].

I. Загашев, С. Заїр-Бек визначають компетентнісний підхід як систему характеристик працівника, які забезпечують можливість ефективно вирішувати не лише актуальні, але й потенційні професійні завдання [7].

Ключовим поняттям у цьому підході є поняття компетентності, яке в педагогіці розуміється по-різному. Як слушно зазначає Н. Бібік, компетентність стосовно структури змісту освіти, що побудована в сучасних стандартах за галузевим принципом і в програмах, виводить універсальний метарівень, що в інтегрованому вигляді представляє освітні результати [2].

У своїх працях О. Овчарук наголошує, що експерти країн Свросоюзу трактують поняття компетентності як здатність застосовувати знання й уміння, що забезпечує активне застосування навчальних досягнень у нових ситуаціях; у дослідженнях ЮНЕСКО компетентність визначається як 
поєднання знань, умінь, цінностей і ставлень, застосовних у повсякденні та професійній діяльності [11].

Дж. Равен стверджує, що компетентність - це специфічна здатність, необхідна для ефективного виконання конкретної дії у певній галузі, яка охоплює вузькоспеціальні знання, уміння, способи мислення, а також відповідальність за свої дії [12].

Аналізуючи праці науковців та враховуючи трактування лідерської компетентності менеджера як сукупності сформованих лідерських якостей (мотивів, знань, лідерських умінь і стійкої лідерської позиції) та практичного досвіду лідерства [8], можемо сформулювати висновок, що сутність компетентнісного підходу до формування лідерської компетентності майбутніх бакалаврів 3 менеджменту 3 позиції сучасної дидактики полягає у цілеспрямованій організації освітнього процесу в університеті, покликаного забезпечити розвиток лідерських якостей науково-педагогічних працівників i студентів, ефективне вирішення актуальних і потенційних професійних завдань майбутнім фахівцем.

Згідно Національної рамки кваліфікацій, інтегральна компетентність для випускника рівня бакалавра (6 рівень) - це здатність розв’язувати складні спеціалізовані задачі та практичні проблеми у певній галузі професійної діяльності або у процесі навчання, що передбачає застосування певних теорій та методів відповідної науки i характеризується комплексністю та невизначеністю умов [10]. Слід наголосити, що бакалавр 3 менеджменту буде успішно розв'язувати складні спеціалізовані задачі та практичні проблеми у професійній діяльності лише за умови сформованої лідерської компетентності як ступеня професійного досвіду у межах конкретної посади та здатності реалізовувати цілі, завдання, функції та технології лідерського управління [6].

Сутність компетентнісного підходу до формування лідерської компетентності майбутніх бакалаврів 3 менеджменту відображено у Програмі розвитку лідерських якостей науково-педагогічних працівників і студентів на 2017-2022 роки (Вищий навчальний заклад Укоопспілки «Полтавський університет економіки і торгівлі»). Ця програма являє собою зміст освіти в університеті, головною метою якої є формування лідерської компетентності студентів.

Розкриття суті дидактичної категорії «зміст освіти», яку відображає вище зазначена програма, дає змогу відповісти на одне з головних питань дидактики «Чого навчати?». Загалом, програми підготовки у вищій школі повинні бути скориговані 3 урахуванням постійного зростання обсягів інформації та сприяти формуванню у студентів навичок, необхідних для подальшої успішної діяльності. Університет має стати спільнотою, де формується особистість високопрофесійного соціально-відповідального 
фахівця-лідера.

Вище зазначене засвідчує, що особливої актуальності на сучасному етапі розвитку вищої школи набуває управлінська лідерська парадигма, яка сьогодні успішно імплементується у переважній більшості українських закладів вищої освіти. Так, Вищим навчальним закладом Укоопспілки «Полтавський університет економіки і торгівлі» розроблена Стратегія розвитку університету на 2017-2022 роки. Однією зі стратегічних цілей $\epsilon$ впровадження лідерської управлінської парадигми. Заходи щодо впровадження парадигми включають Заходи розвитку лідерських якостей (пункт 1.8. «Програма розвитку лідерських якостей науково-педагогічних працівників і студентів на 2017-2022 роки»). Ця програма є доповнюючою складовою кваліфікаційної програми підготовки фахівця, і не лише бакалавра з менеджменту.

Мета програми: формування та розвиток soft skills (м'яких, гнучких навичок). Soft skills - це навички, які дозволяють бути успішними незалежно від специфіки діяльності чи напряму, в якому людина працює. Цей тип навичок важливий як в роботі, так і в житті. При чому, чим вище кар'єрними сходами піднімається працівник, тим більшу роль відіграють ці навички, в той час, як професійні можуть відходити на другий план.

Завдання програми передбачають забезпечення формування таких умінь: міжособової комунікації, бути переконливим, знаходити підхід до людей, вести переговори, вміти працювати в команді, неконфліктність, стресостійкість, тайм-менеджмент, креативність, постійного особистісного розвитку, відкритості до навчання та готовність ділитися знаннями, прагнути до інновацій, готовності до викликів, ініціативності, поставлених цілей, досягнення результату, прийняття рішень, розвитку таланту. Усі ці якості відзначаються як ключові компетенції у сучасних компаніях, які будують свою роботу на засадах лідерства.

Програма розраховані на три категорії слухачів: I категорія студенти, II категорія - науково-педагогічні працівники, III категорія управлінський персонал. Програмою передбачена діагностика, аналіз, формування (за потребою) та розвиток лідерських якостей.

Заходи реалізації програм включають такі форми навчання студентів: майстер-класи, ворк-школи, семінари, тренінги, фільмо-кейси. Спікерами проведення зазначених форм навчання можуть бути фахівці, які виявили готовність і бажання поділитися своїми напрацюваннями та досвідом.

Реалізаційним механізмом впровадження програми $\epsilon$ : науководослідна робота та навчально-тренінгова діяльність. Остання здійснюється у рамках роботи «Школи лідера» (реорганізований клуб «Лідер»). 


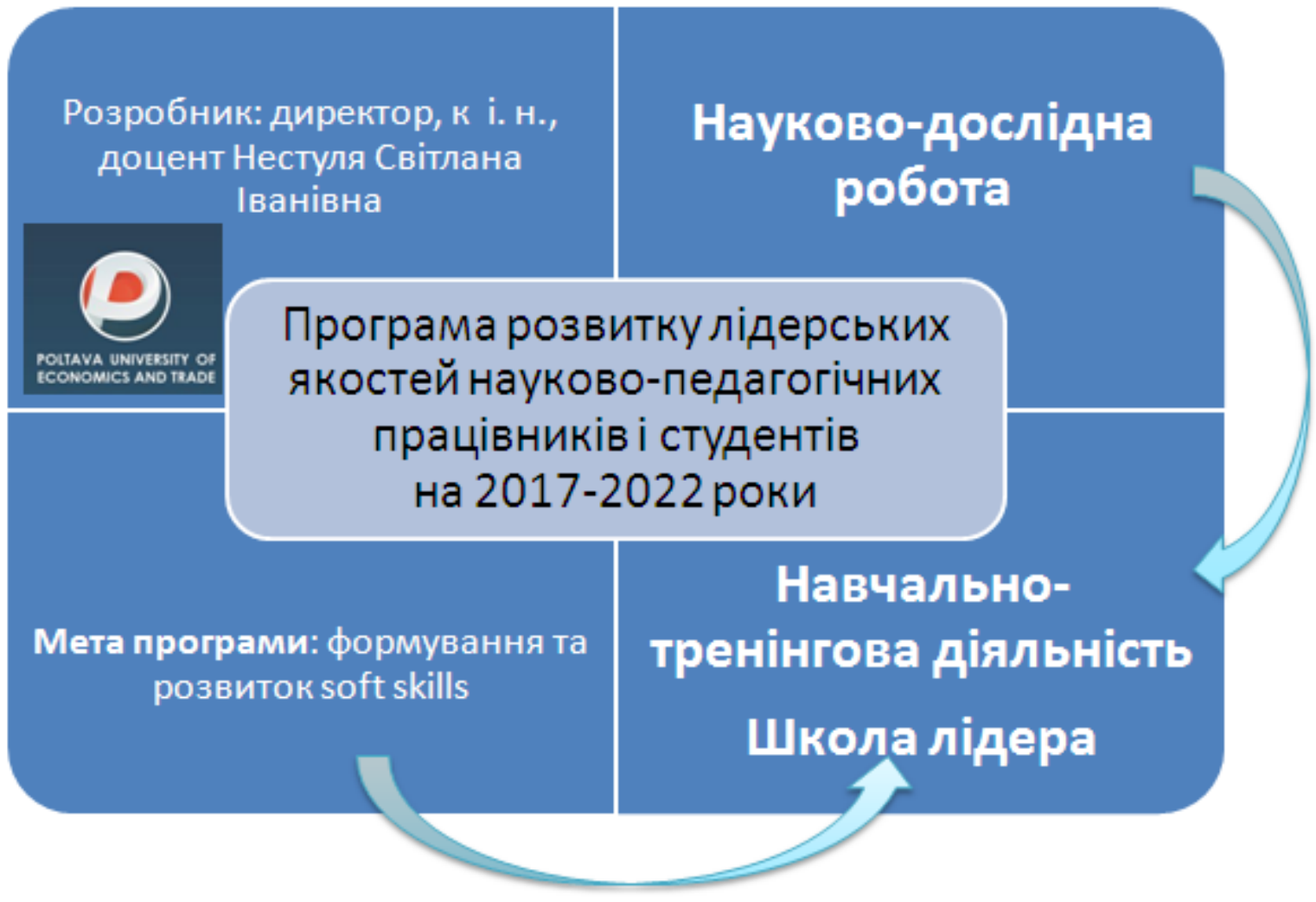

Рис. 1. Реалізаційний механізм впровадження програми

Науково-дослідна робота передбачала у 2017-2018 роках: моніторинг лідерського потенціалу (розробка анкет для моніторингу лідерського потенціалу студентів; розробка анкет для моніторингу лідерського потенціалу науково-педагогічних працівників; розробка анкет для моніторингу лідерського потенціалу адміністративно-управлінського персоналу); участь у проекті TEMPUS «Освіта для лідерства, інтелігентності та розвитку таланту»; підготовка до видання посібника «Основи лідерства. Наукові концепції» англійською мовою; підготовка до видання посібника «Основи лідерства. Самооцінка лідера»

Навчально-тренінгова діяльність для студентської ради передбачала проведення майстер-класу «Лідерство в управлінні», проведення майстеркласу «Розвиток лідерського потенціалу», тренінги «Що таке студентське самоврядування? Його задачі та цілі», «Ефективне планування діяльності органів студентського самоврядування», «Фандрайзинг для органів студентського самоврядування».

Навчально-тренінгова діяльність для студентів передбачала проведення комплексу тренінгів такої тематики: «Особиста ефективність та впевненість у собі», «Особистісне і професійне позиціонування студента-випускника», «Команда», «Мій лідерський потенціал», «Розвиток лідерського потенціалу в управлінні проектами», «Розвиток креативного потенціалу особистості», «Ораторське мистецтво в журналістиці». 
Зміст навчально-тренінгової діяльності для науково-педагогічних працівників університету представлений майстер-класами «Системність як властивість і спосіб існування навколишнього середовища. Системність $\mathrm{i}$ управління. Системність та лідерство», «Лідерство в управлінні», «Особистість в теорії і практиці постмодернізму», «Кризовий менеджмент в умовах ринкових відносин», тренінгами «Тренінгові технології у навчальній діяльності», «Розвиток креативного потенціалу особистості», «Управління конфліктом», «Стрес менеджмент», лекцією «Розвиток людини в умовах глобальної трансформації міжнародних відносин», а також додатковими відкритими тренінгами «Ефективна комунікація», «Ораторське мистецтво» та «Досягнення консенсусу».

Зміст навчально-тренінгової діяльності для адміністративноуправлінського персоналу університету становили тренінги «Досягнення консенсусу», «Стратегічне планування» та «Тайм менеджмент».

Зміст профорієнтаційної роботи 3 майбутніми бакалаврами 3 менеджменту відображено та реалізовано проведенням таких тренінгів, як «Мій лідерський потенціал», «Розвиток лідерського потенціалу в управлінні проектами» та «Розвиток креативного потенціалу особистості».

Слід наголосити, що акцент у навчальній діяльності студентів здійснюється на використанні тренінгових технології. Тренінг, як зазначають О. Дрючило та А. Кордонська, - це запланований процес модифікації відношення, знання чи поведінкових навичок того, хто навчається, через набуття навчального досвіду 3 тим, щоб досягти ефективного виконання в одному виді діяльності або в певній галузі. Тренування розуміється як система підготовки студентів 3 метою пристосування їх до підвищених вимог і складних умов роботи [5]. Тренінгові форми навчання, які застосовувалися у межах реалізації програми, повністю охоплюють весь потенціал студента: рівень та обсяг його компетентності (професійної, соціальної, емоційної, інтелектуальної, лідерської), самостійність, здатність до прийняття рішень, до взаємодії тощо.

Тренінги обраної у межах реалізації програми тематики - це ретельно спланований процес навчання, поповнення знань, відпрацювання умінь i навичок, зміни чи оновлення певних ставлень, поглядів i переконань, розвитку лідерських якостей. Продовжуючи позицію В. Давидюк [4], згідно якої застосування тренінгів $є$ формою педагогіки співробітництва і розвивального навчання, тренінг у процесі формування лідерської компетентності майбутніх бакалаврів з менеджменту - це:

1) нові підходи (співпраця, відкритість, активність, відповідальність, лідерство);

2) нові знання (інтенсивне засвоєння, уточнення, обмін знаннями, побудова знань); 
3) позитивні цінності, ставлення, ідеали, мотивація до формування лідерської компетентності;

4) нові уміння і навички (ефективної комунікації, самоконтролю, лідерства, роботи в команді, уміння надавати й отримувати допомогу, аналіз ситуацій і прийняття рішень тощо).

Ще однісю ефективною формою навчання студентів при формуванні їх лідерської компетентності $\epsilon$ майстер-клас. Як стверджують К. Торн, Д. Маккей, майстер-клас - це одна 3 форм ефективного професійного, активного навчання, яка відрізняється від семінару тим, що під час майстер-класу ведучий-спеціаліст (Майстер) розповідає i, що ще більш важливо, показує, як застосовувати на практиці нову технологію або метод [14]. Зазначимо, що при формуванні лідерської компетентності майбутніх бакалаврів 3 менеджменту без такої форми навчання не обійтися, вона у більшості випадків стає необхідною формою організації та проведення навчальних занять при підготовці студентів в університеті.

Перевага майстер-класу над іншими формами навчання студентів та науково-педагогічних працівників університету в тому що: 1) ідея проведення майстер-класу, спрямована на результативність роботи його «учнів», $\epsilon$ практико-орієнтованою та компетентнісно-орієнтованою; 2) майстер-клас - одна 3 інтерактивних форм професійної взаємодії студентів та педагогів, що вигідно виділяє іiі від традиційних форм навчання; 3) майстер-клас як форма розвитку творчого потенціалу майбутніх менеджерів-лідерів передбачає використання умов співробітництва, співтворчості, спільного пошуку, педагогіки свободи.

Тренінги та майстер-класи, запропоновані у програмі, створюють ефективну тренінгову технологію формування лідерської компетентності майбутніх бакалаврів 3 менеджменту як систему функціонування всіх компонентів освітнього процесу, побудовану на науковій основі, запрограмовану у часі і просторі, яка приведе до наміченого результату позитивної динаміки сформованості лідерської компетентності студентів університету.

Дидактичним забезпеченням реалізації програми $\epsilon$ комплекс традиційних друкованих підручників та посібників, а також електронні засоби навчання, як от електронний курс лекцій з дисципліни «Основи лідерства», тестові завдання, дистанційний курс «Основи лідерства» (рис. 2).

На особливу увагу заслуговує практикум «Тренінг лідерських якостей та практичних навичок менеджера», який $є$ збірником інтерактивних групових та індивідуальних завдань для отримання, розвитку та вдосконалення особистих лідерських якостей студентів та формування лідерської компетентності майбутніх бакалаврів 3 менеджменту [15]. 


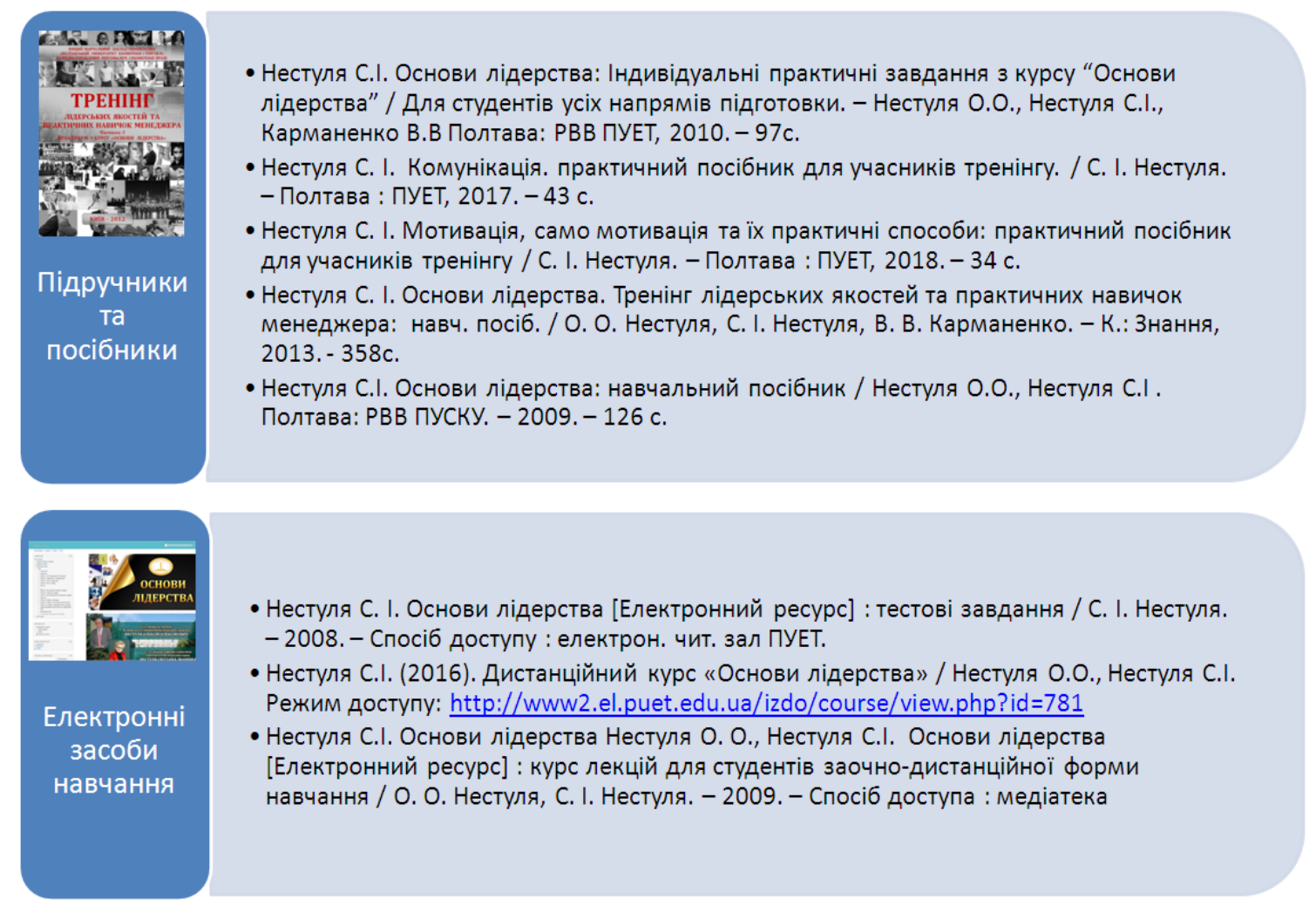

\section{Рис. 2. Дидактичне забезпечення}

Розроблене дидактичне забезпечення спрямоване на реалізацію ключової мети тренінгу - виявлення, формування, розвиток i вдосконалення лідерських якостей. Для досягнення мети поетапно вирішується ряд завдань: формування лідерського світогляду на основі вивчення та засвоєння теоретичних положень сучасної лідерської парадигми та практичного досвіду світових i вітчизняних лідерів; формування управлінських, соціально-психологічних, лідерських якостей та компетенцій, здатних підвищувати ефективність професійної діяльності; формування небайдужої, активної позиції у вирішенні проблем як особистого життя, так і професійної та суспільної сфер діяльності; пробудження (вироблення) мотивації та прагнення до лідерства; сприяння формуванню оптимістичного сприйняття навколишнього середовища, стійкості у стресових і кризових ситуаціях; створення й закріплення позитивного досвіду лідерської поведінки та взаємодії з послідовниками.

Таким чином, сутність компетентнісного підходу до формування лідерської компетентності майбутніх бакалаврів 3 менеджменту з позиції сучасної дидактики полягає у цілеспрямованій організації освітнього процесу в університеті, покликаного забезпечити розвиток лідерських якостей науково-педагогічних працівників i студентів, сприяти ефективному вирішенню актуальних і потенційних професійних завдань. 
Ключовими формами навчання студентів $\epsilon$ тренінгові технології за допомогою яких студенти вчаться визначати основні напрями своєї майбутньої педагогічної професійної діяльності, іï цілі та перспективи, формувати лідерську компетентність, удосконалювати свої рефлексивні характеристики, адаптуватися до майбутньої професійної діяльності, бути успішним управлінцем-лідером. Сутність компетентнісного підходу до формування лідерської компетентності майбутніх бакалаврів 3 менеджменту розкрито у Програмі розвитку лідерських якостей науковопедагогічних працівників і студентів на 2017-2022 роки. Ця програма являє собою зміст освіти в університеті, головною метою якої $\epsilon$ формування лідерської компетентності студентів.

\section{СПИСОК ВИКОРИСТАНИХ ДЖЕРЕЛ}

1. Андрущенко В.П. Модернізація педагогічної освіти України в контексті Болонського процесу. Вища освіта Украӥни. 2004. № 1. C. 5-9.

2. Бібік Н. М. Компетентнісний підхід: рефлексивний аналіз застосування. Компетентнісний підхід у сучасній освіті: світовий досвід та українські перспективи: б-ка з освітньої політики. Київ, 2004. C. 47-52.

3. Болотов В. А., Сериков В. В. Компетентностная модель: от идеи к образовательной программе. Педагогика. 2003. № 10. С. 8-14.

4. Давидюк В. С. Застосування тренінгових технологій на уроках основи здоров'я: навч.-метод. посіб. Березне, 2013. 43 с.

5. Дрючило О. А., Кордонська А. В. Тренінгові технології навчання як засіб розвитку професійних компетенцій майбутніх фахівців. 2013. URL: https://fpo.udpu.edu.ua/wp-content/uploads/2013/10

6. Жигірь В. І. Сутність та зміст лідерської компетентності майбутнього менеджера освіти. 2015. URL: http://visnyk.chnpu.edu.ua/?wpfb_dl=1355

7. Загашев И., Заир-Бек С. Критическое мышление: технология развития. Санкт-Петербург, 2004. 428 с.

8. Мараховська Н. В. Педагогічні умови формування лідерських якостей майбутніх учителів у процесі навчання дисциплін гуманітарного циклу: автореф. дис. на здобуття наук. ступеня канд. пед. наук. Харків, 2009. 22 с.

9. Михайловский В. А. Педагогика высшей школы: учеб. пособие. Харків, 1991. 185 с.

10. Національна рамка кваліфікацій: Постанова Кабінету Міністрів України від 23 листопада 2011 р. № 1341. URL: http://zakon5. rada.gov.ua/laws/show/1341-2011-\%D0\%BF.

11. Овчарук О.В. Розвиток компетентнісного підходу: стратегічні 
орієнтири міжнародної спільноти. Компетентнісний підхід у сучасній освіті: світовий досвід та украӥнські перспективи. Київ, 2004. С. 66-72.

12. Равен Дж. Компетентность в современном обществе: выявление, развитие и реализация / пер. с англ. Москва, 2002. 396 с.

13. Селевко Г. К. Компетентности и их классификация. Народное образование. 2004. № 4. С. 138-143.

14. Торн К., Маккей Д. Полное руководство по тренингу / пер. с англ. Москва, 2002. 244 с.

15. Нестуля С. І., Нестуля О. О., Карманенко В. В. Основи лідерства. Тренінг лідерських якостей та практичних навичок менеджера: навч. посіб. Київ: Знання, 2013. 287 с. 